Boos, R. N., Carr, J. E. \& Conn, J. B. (1953). Science, 117, 603.

Brown, F. B., Cain, J. C., Gant, D. E., Parker, L. F. J. \& Smith, E. L. (1955). Biochem. J. 59, 82.

Brownstein, A. M. \& Abeles, R. H. (1961). J. biol. Chem. 236, 1199.

Clark, L. C. (1956). Trans. Amer. Soc. artif. intern. Organs, 2 , 41.

Connelly, C. M. (1957). Fed. Proc. 16, 681.

Diehl, H. \& Murie, R. (1952). Iowa St. Coll. J. Sci. 26, 555.

Dixon, M., Maynard, J. M. \& Morrow, P. F. W. (1960). Nature, Lond., 186, 1032.

Dubnoff, J. W. (1950). Arch. Biochem. 27, 466.

Dubnoff, J. W. \& Bartron, E. (1956). Arch. Biochem. Biophys. 62, 86.

Eggerer, H., Stadtman, E. R., Overath, P. \& Lynen, F. (1960). Biochem. Z. 333, 1.

Ford, J. E. \& Porter, J. W. G. (1953). Brit. J. Nutr. 7, 326.

Guest, J. R., Friedman, S., Woods, D. D. \& Smith, E. L. (1962). Nature, Lond., 195, 340.

Harrison, D. C. (1924). Biochem. J. 18, 1009.
Jukes, T. H. \& Williams, W. L. (1954).' In The Vitamins, vol. 1, p. 476. Ed. by Sebrell, W. H. \& Harris, R. S. New York: Academic Press Inc.

Krebs, H. A. (1929). Biochem. Z. 204, 322.

Lenhert, P. G. \& Hodgkin, D. C. (1961). Nature, Lond., 192 , 937.

Meiklejohn, G. T. \& Stewart, C. P. (1941). Biochem. J. 35, 755.

Peel, J. L. (1962a). J. biol. Chem. 237, PC 263.

Peel, J. L. (1962b). Biochem. J. 85, 17 P.

Rabinowitz, J. C. (1960). J. biol. Chem. 235, PC50.

Rabinowitz, J. C. \& Allen, E. H. (1961). Fed. Proc. 20, 962.

Smith, E. L. (1960). Vitamin $B_{12}$. London: Methuen and Co. Ltd.

Stickland, R. G. (1960). Biochem. J. 77, 636.

Toohey, J. I. \& Barker, H. A. (1961). J. biol. Chem. 236 , 560.

Volcani, B. E., Toohey, J. I. \& Barker, H. A. (1961). Arch. Biochem. Biophys. 92, 381.

Warburg, O. (1949). Heavy Metal Prosthetic Groups and Enzyme Action, pp. 34-45. Oxford: Clarendon Press.

Woodward, G. E. \& Fry, E. G. (1932). J. biol. Chem. 97, 465.

Biochem. J. (1963) 88, 308

\title{
The Metabolism of Progesterone in Man
}

\section{EXTRACTION AND SEPARATION BY COUNTERCURRENT DISTRIBUTION OF THE METABOLITES IN URINE}

\author{
By R. A. HARKNESS AND K. FOTHERBY* \\ Clinical Endocrinology Research Unit (Medical Research Council), University of Edinburgh
}

(Received 11 February 1963)

After the administration of $\left[4-{ }^{14} \mathrm{C}\right]$ progesterone or $\left[16-{ }^{3} \mathrm{H}\right]$ progesterone to humans, $15-61 \%$ of the dose was recovered from the urine and 13-28\% from the faeces (Gallagher et al. 1954; Pearlman, 1957 ; Davis \& Plotz, 1958; Sandberg \& Slaunwhite, 1958). The known metabolites of progesterone in urine, $5 \beta$-pregnane-3 $\alpha, 20 \alpha$-diol (pregnanediol), $3 \alpha$ hydroxy-5 $\beta$-pregnan-20-one (pregnanolone) and their isomers, account for less than one-third of the administered hormone, so that much of the radioactivity present in urine must reside in compounds other than the above metabolites, if hydrolysis of the conjugates of the above steroids in urine has been complete. In an attempt to identify these unknown metabolites the metabolism of $\left[4^{-14} \mathrm{C}\right]$ progesterone in man has been investigated. The present paper describes a study of the hydrolysis and extraction of the metabolites of $\left[4^{-14} \mathrm{C}\right]$ progesterone from the urine of ovariectomized

* Present address: Postgraduate Medical School, Ducane Road, London, W. 12. adrenalectomized women who had received the labelled hormone, and the preliminary separation of these metabolites by countercurrent distribution.

\section{METHODS}

\section{Subjects}

The subjects were five women (aged 41-59 years) who had been adrenalectomized and ovariectomized for mammary carcinoma. All subjects were in hospital during the investigation and were ambulant; they were receiving 25$37.5 \mathrm{mg}$. of cortisone acetate daily, by mouth, as replacement therapy. There was no evidence of impairment of hepatic or renal function. All subjects collected complete $24 \mathrm{hr}$. samples of urine for 9-14 days from the day of injection of $\left[4-{ }^{14} \mathrm{C}\right]$ progesterone.

\section{Administration of $\left[4-{ }^{14} \mathrm{C}\right]$ progesterone}

Subject A.W. received $20 \mu \mathrm{C}\left(0 \cdot 3 \mathrm{mg}\right.$.) of $\left[{ }^{\left[-{ }^{14}\right.} \mathrm{C}\right]$ progesterone (The Radiochemical Centre, Amersham, Bucks.) intravenously over about $15 \mathrm{~min}$. The steroid was administered by dissolving it in $20 \mathrm{ml}$. of $0.9 \%$ sodium chloride in 
ethanol-water $(1: 9, v / v)$ and injecting the solution into the tubing of an intravenous-drip set. Each of four other subjects (B, S, Y and $\mathrm{M})$ received $2 \mu \mathrm{C}(0.03 \mathrm{mg}$.) of [4-14 $\mathrm{C}]$ progesterone in $20 \mathrm{ml}$. of $0.9 \%$ sodium chloride in ethanol-water $(1: 9$, $\mathrm{v} / \mathrm{v}$ ) injected intravenously over about $5 \mathrm{~min}$. All apparatus used for preparing and injecting the dose was washed five times with ethyl acetate, the radioactivity of the washings determined and the injected dose calculated. In each case about $95 \%$ or more of the dispensed dose was administered. Paper chromatography of the $\left[4^{14} \mathrm{C}\right]$ progesterone in the solvent system light petroleum (b.p. 80-100 )-methanolwater (5:4:1, by vol.) showed that $98 \%$ of the radioactivity had the same $R_{F}$ as progesterone.

\section{Chemical methods}

Experiments on the hydrolysis and extraction of the metabolites in urine. For these experiments the urine excreted during the first 3 days after the injection of $\left[4-{ }^{14} \mathrm{C}\right]$ progesterone was combined, and the yields of radioactivity obtained by the various procedures are expressed as percentages of the total radioactivity in these combined samples. For the determination of the amount of radioactivity extracted by chloroform or light petroleum (b.p. $\left.80-100^{\circ}\right)$ before hydrolysis, urine $(50 \mathrm{ml}$.) was adjusted to the required $\mathrm{pH}$ and extracted with 2 vol. of the organic solvent.

For enzymic hydrolyses $\beta$-glucuronidase was prepared as described by Fotherby \& Love (1960) from the common limpet (Patella vulgata); the preparations had activities of $1.5 \times 10^{6}-3.0 \times 10^{6}$ Fishman units/g. Urine was adjusted to pH 4.7 and $0 \cdot 1$ vol. of $\mathrm{M}$-acetate buffer, pH $4 \cdot 7$, and the required amount of enzyme powder were added; the mixture was well shaken and incubated at $37^{\circ}$. After incubation the urine was twice extracted with $2 \mathrm{vol}$. of chloroform. Acid hydrolysis was performed by boiling the urine with $0.15 \mathrm{vol}$. of conc. hydrochloric acid for $20 \mathrm{~min}$.; after cooling, the urine was extracted twice with 2 vol. of chloroform.

The chloroform and light petroleum extracts were washed once with $0.1 \mathrm{vol}$. of $0.1 \mathrm{~N}$-sodium hydroxide, twice with 0.1 vol. of water, dried with anhydrous sodium sulphate and a measured sample of the dried extract was evaporated to dryness under an air blast. The residue obtained was dissolved in ethanol and a sample of this solution used for the determination of radioactivity.

Extraction with butanol was performed by extracting the urine, after acidification to the required $\mathrm{pH}$, three times with 0.33 vol. of butanol. The butanol extract was washed once with 0.1 vol. of water, neutralized with ethanolic potassium hydroxide if necessary, and evaporated to dryness under reduced pressure.

Extraction of urine from subject $A . W$. receiving $20 \mu \mathrm{c}$ of $\left[4-{ }^{14} \mathrm{C}\right]$ progesterone. Because substantial amounts of unconjugated metabolites of the $\left[4^{-14} \mathrm{C}\right]$ progesterone were unlikely to be excreted for more than $48 \mathrm{hr}$. after injection of the hormone, only the first two $24 \mathrm{hr}$. collections of urine were extracted with 2 vol. of chloroform to give a 'freely extractable fraction'. The urine was then adjusted to $\mathrm{pH}$ $4 \cdot 7$, and 0.1 vol. of $\mathrm{M}$-acetate buffer, $\mathrm{pH} 4 \cdot 7$, and a quantity of enzyme sufficient to produce a concentration of 1000 units/ml. were added; the mixture was incubated for $72 \mathrm{hr}$. at $37^{\circ}$. A similar quantity of enzyme was added 24 and $48 \mathrm{hr}$. after commencement of the incubation. The urine was extracted with 2 vol. of chloroform to give the enzymehydrolysed fraction. The extracted urine was boiled for $20 \mathrm{~min}$. with $0.15 \mathrm{vol}$. of conc. hydrochloric acid and the urine extracted with 2 vol. of chloroform to give the acidhydrolysed fraction. The residual urine was then extracted three times with $0.33 \mathrm{vol}$. of butanol, and the butanol extract was washed once with 0.1 vol. of water, neutralized with ethanolic potassium hydroxide and evaporated to dryness under reduced pressure. Each chloroform extract was washed once with $0.1 \mathrm{vol}$. of $0.1 \mathrm{~N}$-sodium hydroxide, twice with $0 \cdot 1$ vol. of water, dried with anhydrous sodium sulphate and evaporated to dryness under reduced pressure. The aqueous phases from washing the chloroform extract of the first 3 days' urine samples after enzymic hydrolysis were extracted with 1 vol. of chloroform and this chloroform extract was added to the enzyme-hydrolysed fraction.

The residues obtained from each chloroform extract were separated into a non-ketonic fraction and a ketonic fraction by use of Girard's reagent T, according to the procedure described by Fotherby, Colas, Atherden \& Marrian (1957), and each fraction was subjected to countercurrent distribution for 100 cycles with the solvent system cyclohexaneethyl acetate-ethanol-water $(7: 3: 5: 5$, by vol.). For the countercurrent distributions a 100-tube all-glass apparatus of the type described by Craig, Hausmann, Ahrens \& Harfenist (1951) was used. Upper- and lower-phase volumes of $40 \mathrm{ml}$. each were used throughout the investigation. The degree of resolution obtained during the countercurrent distribution was determined by determination of the radioactivity in every third tube of the apparatus.

Determination of radioactivity. The radioactivity of those samples that were soluble in organic solvents was determined by liquid-scintillation counting by using the Nuclear Enterprises assembly NE 8301 [Nuclear Enterprises (Great Britain) Ltd., Sighthill, Edinburgh] and an Ekco automatic scaler type N530F. The instrumental settings were selected by the method of Haigh (1954) to obtain minimum error in the counting of weak sources of radioactivity. No upper limit was set to the energy of the impulses which were counted. Water was slowly passed through the head unit for at least $30 \mathrm{~min}$. before counting was started and during counting. The end-window of the counting vessel, containing the sample dissolved in $3 \mathrm{ml}$. of NE213 scintillator, was blotted with filter paper and carefully wiped with chamois leather (Stitch, 1959). The vessel was then placed in the counting head for at least $3 \mathrm{~min}$. before counting was commenced (Brown \& Badman, 1961). A minimum of 1000 counts was recorded; whenever possible the size of the sample was chosen to give a high counting rate of $1000-2000$ counts/100 sec. In this way the effect of variations in the background, such as those described by Peng (1960), on the observed counting rate of the radioactive sample could be neglected. Under these conditions the efficiency for counting ${ }^{14} \mathrm{C}$ was about $85 \%$. Counting rates from a radioactive sample of $10 \%$ or less of the background counting rate were not used. The degree of quenching produced by the sample was estimated by adding $2 \mu \mathrm{C}$ of $\left[4^{-14} \mathrm{C}\right]$ progesterone in $0 \cdot 1 \mathrm{ml}$. of benzene to the sample and noting the reduction in the counting rate from the expected value. Falsely high counting rates were observed when crude extracts were dissolved in the scintillator; as a result of this chemiluminescence (Swank, 1958) crude samples were counted by gas-flow proportional counting by using the Tracerlab windowless automatic counter 
assembly with a $\mathbf{P} 30$ proportional pre-amplifier (Tracerlab Inc., Waltham, Mass., U.S.A.) and argon-methane (9:1, $\nabla / \nabla)$ as the counting gas. The instrumental settings were selected to obtain minimum error in the counting of weak sources of radioactivity (Haigh, 1954). The sample to be counted was dissolved in water or ethanol and a volume of $0.5 \mathrm{ml}$. or more pipetted on to a nickel-plated steel planchet (diam. 1 in.). The solvent was slowly evaporated from the sample by an infrared lamp while the planchets were on a slowly rotating turntable canted at $5^{\circ}$. From the weight of the residue the counting rate from the samples was corrected to that at infinite thinness. Under the above conditions the counting efficiency was about $60 \%$ for ${ }^{14} \mathrm{C}$. Because of the different efficiencies of the methods used, all counting rates were corrected to an efficiency of $100 \%$ by using the same standard of $\left[4-{ }^{14} \mathrm{C}\right]$ progesterone.

\section{RESULTS}

Excretion of the administered radioactivity in the urine. The percentage of administered radioactivity recovered in the urine varied widely. Most of the radioactivity recovered was excreted within 4 days of the injection although small amounts of radioactivity continued to be excreted for at least 11 days after the injection. The results are shown in Table 1.

Extraction of metabolites by an organic solvent before hydrolysis. The amount of radioactivity extracted from the urine before hydrolysis depended on the solvent used for the extraction and the pH of the urine (Table 2). Butanol, which is known to extract steroid conjugates from urine, especially after acidification (Cohen \& Marrian, 1936), extracted more radioactivity than could be recovered after hydrolysis of the urine with acid or with a $\beta$-glucuronidase preparation. As expected, chloroform and light petroleum were much less efficient in extracting the radioactivity from urine. It was noted that the partition coefficient of the metabolites extracted by chloroform from acidified urine in the solvent system used for the countercurrent distribution was much smaller than that for pregnanediol $(K=1 \cdot 3)$ in the same system. This fact, and the increased yield obtained with chloroform after acidification of the urine, suggested that chloroform was extracting some steroid conjugates in addition to any unconjugated steroids that were present. The amount of radioactivity recovered by the use of light petroleum did not vary with the $\mathrm{pH}$ of the urine, and the partition coefficient for the extracted radioactivity showed that the compounds extracted were less polar than pregnanediol. It was shown that more than $80 \%$ of added pregnanediol could be extracted from water by 2 vol. of light petroleum.

Extraction of metabolites after enzymic hydrolysis. After incubation of the urine with a $\beta$-glucuronidase preparation at a concentration of 1000 units $/ \mathrm{ml}$. for 18-24 hr., 51·1, 53.4, 65 and $59 \%$ of the radioactivity present in the urine of subjects $B, Y, S$ and

Table 1. Daily excretion of radioactivity as a percentage of the radioactivity of administered $\left[4-{ }^{14} \mathrm{C}\right]$ progesterone

Experimental details are given in the text.

\begin{tabular}{|c|c|c|c|}
\hline \multirow[b]{2}{*}{ Day } & \multicolumn{3}{|c|}{$\begin{array}{l}\text { Percentage of administered } \\
\text { radioactivity excreted on } \\
\text { each day }\end{array}$} \\
\hline & Subject $M$ & Subject $\mathrm{S}$ & Subject I \\
\hline 1 & $39 \cdot 8$ & $45 \cdot 6$ & $29 \cdot 7$ \\
\hline 2 & $15 \cdot 3$ & $6 \cdot 8$ & 8.8 \\
\hline 3 & $8 \cdot 1$ & $5 \cdot 6$ & $4 \cdot 7$ \\
\hline 4 & 4.9 & $2 \cdot 2$ & $4 \cdot 0$ \\
\hline 5 & $2 \cdot 6$ & $1 \cdot 4$ & 1.6 \\
\hline 6 & $2 \cdot 3$ & $1 \cdot 1$ & 1.2 \\
\hline 7 & 1.6 & 1.0 & 0.4 \\
\hline 8 & $1 \cdot 1$ & 0.3 & $0 . \overline{3}$ \\
\hline $\mathbf{9}$ & 1.0 & 0.2 & 0.2 \\
\hline 10 & 0.5 & - & \\
\hline 11 & - & - & 0.7 \\
\hline Total & $77 \cdot 2$ & $64 \cdot 2$ & $51 \cdot 6$ \\
\hline
\end{tabular}

Table 2. Effect of change in the $\mathrm{pH}$ of urine on the extraction of radioactivity by organic solvents before hydrolysis, after the administration of $\left[4-{ }^{14} \mathrm{C}\right]$ progesterone

Experimental details are given in the text. $K$, Partition coefficient of extracted radioactivity in the solvent system cyclohexano-othyl acetato-ethanol-water $(7: 3: 5: 5$, by vol.).

\begin{tabular}{|c|c|c|c|c|}
\hline \multirow{3}{*}{$\begin{array}{c}\text { Solvent } \\
\text { Light petroleum }\end{array}$} & \multirow{3}{*}{$\begin{array}{c}\text { Subject } \\
\text { M }\end{array}$} & \multicolumn{3}{|c|}{$\begin{array}{l}\text { Percentage of radioactivity extracted } \\
\text { from urine }\end{array}$} \\
\hline & & At pH 1 & At $\mathrm{pH} 4 \cdot 7$ & At $\mathrm{pH} 7$ \\
\hline & & $\begin{array}{l}0.54 \\
(K=2 \cdot 2)\end{array}$ & & $\begin{array}{c}0.55 \\
(K=2 \cdot 7) \\
0.7\end{array}$ \\
\hline Chloroform & $\mathbf{M}$ & $\left(\begin{array}{c}2.9 \\
=0 \cdot 8 \\
11.5\end{array}\right)$ & $1 \cdot 65$ & $\left(\begin{array}{l}1.55 \\
=1 \cdot 25 \\
5.6\end{array}\right.$ \\
\hline Butanol & $\begin{array}{l}\mathbf{M} \\
\mathbf{S} \\
\mathbf{B}\end{array}$ & $\begin{array}{l}\mathbf{7 4 \cdot 7} \\
85 \cdot 0 \\
91 \cdot 0\end{array}$ & $=$ & $\begin{array}{r}46 \cdot 2 \\
-\end{array}$ \\
\hline
\end{tabular}


M respectively was extracted by chloroform. Incubation for up to 5 days or with concentrations of enzyme as high as 5000 units $/ \mathrm{ml}$. of urine led to an increase of about $10 \%$ in the recovery of radioactivity. Most of the radioactivity released by the enzyme preparation was recovered from the urine by a single extraction with 2 vol. of chloroform. Thus, with the urine from subject $S, 58 \%$ of the radioactivity in the urine was recovered in the first chloroform extract and about $7 \%$ in the second. By further extraction only another $2 \%$ of the radioactivity was obtained and the partition coefficient of this radioactivity was $0 \cdot 3-0.4$, in contrast with the value of about 1 for the radioactivity in the first chloroform extract. After removal from the urine of about $70 \%$ of the radioactivity by enzymic hydrolysis and extraction with chloroform, another $13-15 \%$ of the radioactivity in the urine could be extracted by acidifying the urine to pH 1 and extracting with butanol.

The use of an excessive amount of the enzyme preparation may result in a lowered recovery of radioactivity. When urine, to which known amounts of unconjugated radioactive metabolites had been added, was incubated with various amounts of enzyme for $45 \mathrm{hr}$. and extracted with chloroform, the recovery of added radioactivity decreased as the amount of enzyme used increased (Table 3). An analysis of variance showed that the effect of the different enzyme concentrations was statistically significant $(P<0.01)$.

Abul-Fadl (1957) and Marsh (1961) have shown that inhibitors of $\beta$-glucuronidase, one of which behaves like saccharo-( $1 \rightarrow 4)$-lactone, occur in urine. One procedure that has been used to decrease inhibition of the enzyme is to add further amounts of enzyme at intervals after the commencement of the incubation, in the way described in the Methods section for the enzymic hydrolysis of the urine from subject A.W. By using two additions of enzyme the recovery of radioactivity from urine of subjects $Y$ and $S$ was increased by about $10 \%$. Since Levvy (1952) has shown that saccharo- $(1 \rightarrow 4)$-lactone is unstable in aqueous solution at $\mathrm{pH} 7$ an alternative method of overcoming the inhibition was tried. Samples of urine from subjects $\mathbf{Y}$ and $\mathbf{M}$ were incubated at about $\mathrm{pH} 7$ for $24 \mathrm{hr}$. and then incubated for $24 \mathrm{hr}$. with the enzyme at a concentration of 1000 units $/ \mathrm{ml}$. of urine. Although the yield of radioactivity from the urine of subject $Y$ by this procedure (58\%) was higher than that (47\%) obtained by incubating similar samples of urine with the same concentration of enzyme for $48 \mathrm{hr}$., there was no marked difference between the yields of radioactivity from urine of subject $M$ for the two procedures (59 and 56.6\% respectively).

Extraction of metabolites excreted as sulphates. Continuous extraction with ether of urine that has been hydrolysed with a $\beta$-glucuronidase preparation, extracted with an organic solvent and adjusted to $\mathrm{pH}$ 1, has been widely used to hydrolyse steroid sulphates in urine, although steroids other than those originally present as sulphates may be released by this procedure. By using this method 3.1 and $8.5 \%$ of the total radioactivity in the urine was recovered from the urine of subjects $M$ and $B$ respectively. A more accurate estimate of the radioactivity conjugated with sulphuric acid was obtained by using the solvolysis procedure of Burstein \& Lieberman (1958), or the method of McKenna \& Norymberski (1960), in which the steroid sulphates are extracted as the pyridinium salts. By the former method 2.8 and $8.5 \%$ of the radioactivity was extracted from the urine of subjects $M$ and $Y$ respectively, and by the latter method $2.5 \%$ of the radioactivity was obtained from the urine of subject $M$.

Extraction of metabolites after hydrolysis of the urine with acid. The amount of radioactivity extracted by chloroform from urine that had been boiled with 0.15 vol. of conc. hydrochloric acid for 20 min. is shown in Table 4. With some urines a

Table 3. Effect of different concentrations of $\beta$ glucuronidase preparation on the recovery of added unconjugated radioactive steroids from urine after the administration of $\left[{ }^{4-14} \mathrm{C}\right]$ progesterone

Urine (10 ml.) was adjusted to $\mathrm{pH} \mathrm{4.7,1} \mathrm{ml.} \mathrm{of} \mathrm{M-acetate}$ buffer, $\mathrm{pH} 4 \cdot 7$, and the amounts of enzyme shown below were added followed by $0 \cdot 1 \mathrm{ml}$. $(4 \cdot 8 \mu \mathrm{mc})$ of a solution of a mixture of radioactive steroids in ethanol. The mixture was incubated for $45 \mathrm{hr}$. at $37^{\circ}$, extracted with chloroform and the radioactivity in the chloroform extract determined. The mixture of radioactive steroids was obtained by chloroform extraction after enzymic hydrolysis of urine from a patient receiving $\left[4-{ }^{14} \mathrm{C}\right]$ progesterone.

$\begin{array}{ccc}\begin{array}{c}\text { Wt. of enzyme } \\ \text { preparation } \\ \text { Enzyme activity } \\ \text { added (mg./ml. } \\ \text { of urine) }\end{array} & \begin{array}{c}\text { Recovery of } \\ \text { radioactivity } \\ \text { (units/ml. of urine) }\end{array} \\ 0 & 0 & 92 \cdot 3,92 \cdot 2 \\ 1000 & 0 \cdot 67 & \mathbf{8 6 \cdot 8 , 9 1 \cdot 3} \\ 3000 & 2 \cdot 01 & \mathbf{8 3 \cdot 5 , 8 1 \cdot 0} \\ 5000 & \mathbf{3 \cdot 3 5} & \mathbf{8 0 \cdot 3 , 7 9 \cdot 6}\end{array}$

Table 4. Recovery of radioactivity after hydrolysis of the urine with acid, after the administration of $\left[4-{ }^{14} \mathrm{C}\right]$ progesterone

Experimental details are given in the text.

Percentage of radioactivity extracted from urine by chloroform

$\begin{array}{ccc}\text { Subject } & \begin{array}{c}\text { After first period } \\ \text { of hydrolysis }\end{array} & \begin{array}{c}\text { After reboiling } \\ \text { extracted urine }\end{array} \\ \text { M } & 61 \cdot 7 & 4 \cdot 8 \\ \text { S } & 76.0 & 15 \cdot 5 \\ \text { Y } & 68 \cdot 0 & 3.5\end{array}$


significant amount of radioactivity was recovered by extracting the urine after reboiling for a further $20 \mathrm{~min}$. The use of an overlay of toluene during the hydrolysis increased the amount of radioactivity recovered after the first period of heating, and correspondingly decreased the amount of radioactivity obtained by extraction after reboiling. Thus, with urine from subject $M$, after the first period of hydrolysis $64.6 \%$ of the radioactivity was recovered in the toluene overlay and $4.8 \%$ by extraction of the urine with chloroform; after reboiling this extracted urine, only a small amount of radioactivity $(0.8 \%)$ was recovered.

Preliminary separation of the metabolites extracted from the urine of subject $A . W$. receiving $20 \mu \mathrm{c}$ of $\left[4^{-14} \mathrm{C}\right]$ progesterone. As described in the Methods section the urine from A.W. was hydrolysed and extracted to give four fractions : (1) a freely extractable fraction that contained $4 \%$ of the radioactivity in the administered dose; (2) a fraction obtained after enzymic hydrolysis (31\% of the administered dose); (3) a fraction obtained after boiling the urine with acid $(4 \cdot 4 \%)$; (4) the butanol-extractable fraction $(4.5 \%)$. Thus $44 \%$ of the radioactivity in the administered dose was recovered from the urine.
Fractions (1), (2) and (3) were separated into non-ketonic and ketonic fractions and each fraction was subjected to countercurrent distribution for 100 cycles. After distribution the non-ketonic fraction of the enzyme-hydrolysed fraction was divided into four components: (a) a polar component occupying tubes 0-12 of the distribution; (b) a medium polar component (tubes 13-39); (c) a less polar component (tubes 40-75); (d) a non-polar component (tubes 76-99). The ketonic fraction was also divided into four components: ( $a$ ) a polar component (tubes 0-28); (b) a medium polar component (tubes 29$54)$; (c) a less polar component (tubes 55-84); $(d)$ a non-polar component (tubes 85-99). The amount of radioactivity in each component of the enzymehydrolysed fraction and in the corresponding components of the freely extractable fraction are shown in Table 5. The distribution patterns of the nonketonic and ketonic fractions of the acid-hydrolysed extract were different from those of the freely extractable and enzyme-hydrolysed extracts. The division of the acid-hydrolysed extract into its various components and the proportion of radioactivity detected in each component are shown in Table 6.

Table 5. Percentage of radioactivity in each component obtained by countercurrent distribution of the freely extractable and enzyme-hydrolysed extracts from urine after the administration of $\left[4-{ }^{14} \mathrm{C}\right]$ progesterone

Experimental details are given in the text. Values in row $(a)$ show the ratios of the amount of radioactivity in the non-ketonic fraction to that in the ketonic fraction for each of the extracts.

\begin{tabular}{|c|c|c|c|c|}
\hline \multirow{3}{*}{ Component } & \multicolumn{4}{|c|}{ Percentage of radioactivity } \\
\hline & \multicolumn{2}{|c|}{$\begin{array}{c}\text { In freely } \\
\text { extractable extract }\end{array}$} & \multicolumn{2}{|c|}{$\begin{array}{c}\text { In enzyme- } \\
\text { hydrolysed extract }\end{array}$} \\
\hline & $\begin{array}{l}\text { Non-ketonic } \\
\text { fraction }\end{array}$ & $\begin{array}{l}\text { Ketonic } \\
\text { fraction }\end{array}$ & $\begin{array}{l}\text { Non-ketonic } \\
\text { fraction }\end{array}$ & $\begin{array}{l}\text { Ketonic } \\
\text { fraction }\end{array}$ \\
\hline$(a) \ldots$ & $\begin{array}{ll}\ldots & 7 \cdot 8\end{array}$ & & $15 \cdot 4$ & \\
\hline Polar & $1 \cdot 65$ & $22 \cdot 8$ & $2 \cdot 4$ & $57 \cdot 3$ \\
\hline Medium polar & $4 \cdot 15$ & $23 \cdot 8$ & $4 \cdot 6$ & $27 \cdot 7$ \\
\hline Less polar & $88 \cdot 2$ & $53 \cdot 4$ & $90 \cdot 1$ & $14 \cdot 4$ \\
\hline Non-polar & $6 \cdot 0$ & 0 & $2 \cdot 9$ & $0 \cdot 6$ \\
\hline
\end{tabular}

Table 6. Percentage of radioactivity in the components obtained by countercurrent distributior of the nonketonic and ketonic fractions of the acid-hydrolysed extract of urine, after the administration of $\left[4-{ }^{14} \mathrm{C}\right]-$ progesterone

Experimental details are given in the text. The ratio of radioactivity in the non-ketonic fraction to that in the ketonic fraction was 18:1.

\begin{tabular}{|c|c|}
\hline \multicolumn{2}{|c|}{ Non-ketonic fraction } \\
\hline $\begin{array}{l}\text { Components of } \\
\text { the distribution } \\
\text { (tube no.) }\end{array}$ & $\begin{array}{l}\text { Percentage of } \\
\text { radioactivity } \\
\text { in components }\end{array}$ \\
\hline $\begin{array}{r}0-33 \\
\mathbf{3 4 - 5 3}\end{array}$ & $\begin{array}{r}38 \cdot 8 \\
9 \cdot 0\end{array}$ \\
\hline $54-75$ & $29 \cdot 0$ \\
\hline $76-85$ & 2.9 \\
\hline $86-99$ & $20 \cdot 3$ \\
\hline
\end{tabular}

\begin{tabular}{|c|c|}
\hline \multicolumn{2}{|c|}{ Ketonic fraction } \\
\hline $\begin{array}{l}\text { Components of } \\
\text { the distribution } \\
\text { (tube no.) }\end{array}$ & $\begin{array}{l}\text { Percentage of } \\
\text { radioactivity } \\
\text { in components }\end{array}$ \\
\hline $0-6$ & $45 \cdot 7$ \\
\hline $7-40$ & $36 \cdot 4$ \\
\hline 41-54 & $5 \cdot 1$ \\
\hline $55-68$ & $3 \cdot 5$ \\
\hline $69-90$ & $6 \cdot 5$ \\
\hline 91-99 & $2 \cdot 8$ \\
\hline
\end{tabular}


The shape of the distribution patterns showed that each of the components in Tables 5 and 6 contained a number of compounds. In the distributions there was no band of material producing quenching in the determination of radioactivity that might have led to the false separation of a peak of radioactivity.

\section{DISCUSSION}

The range of recovery of radioactivity from the urine of the subjects who received radioactive progesterone in the present study was similar to that reported by previous workers. Gallagher et al. (1954) recovered $33 \%$ of the administered dose in the urine within 7 days, Davis \& Plotz (1958) reported a range of $15-61 \%$ (mean $35 \%$ ) and Sandberg \& Slaunwhite (1958) found 46-59\% excreted within 5 days. Our findings also confirm those of Davis \& Plotz (1958) that, whereas most of the radioactivity was excreted within 4 days of the administration of $\left[4^{-14} \mathrm{C}\right]$ progesterone, some radioactivity was still detectable in the urine during the next 6-10 days even after intravenous injection of the hormone. This slow excretion of the injected hormone may possibly be due to its storage in fat (Davis \& Plotz, 1958).

In their studies on the extraction of radioactivity from urine, Sandberg \& Slaunwhite (1958) obtained results similar to those reported here. Before hydrolysis of the urine less than $5 \%$ of the radioactivity was extracted by methylene dichloride. In the present study about $0 \cdot 5-1 \%$ of the radioactivity was recovered from the urine by extraction with light petroleum, suggesting that very little of the injected progesterone was excreted as unconjugated metabolites; however, this solvent would not extract any of the more polar metabolites of progesterone that were excreted in the unconjugated state. Although chloroform extracted more radioactivity than light petroleum the increased yield of radioactivity from acidified urine compared with that from unacidified urine suggested that some of the metabolites extracted by this solvent were either conjugated with acids or were themselves acidic. Whether the small amount of radioactivity freely extractable from urine was excreted in the unconjugated state or arose from hydrolysis occurring during the collection and storage of the urine, or its subsequent treatment, is unknown. In our experience the amount of radioactivity freely extractable from urine increased with the length of time for which the urine was stored. For example, after storage of the urine of subject $B$ for 4 weeks at $4^{\circ}, 88 \%$ of the total urinary radioactivity was extracted by chloroform without applying any hydrolytic procedure. These spontaneous changes may have been due to bacteria (Bucher \& Geschickter, 1940).
In their preliminary studies Gallagher et al. (1954) found that if, after enzymic hydrolysis with a $\beta$-glucuronidase preparation from ox liver, the urine was acidified to $\mathrm{pH} 1$, almost all of the radioactivity was recovered by continuous extraction for $48 \mathrm{hr}$. with ether, whereas, after continuous extraction at $\mathrm{pH} 5,10 \%$ of the radioactivity remained in the urine. Thus these workers were able to extract almost all of the radioactivity from the urine and suggested that most of the metabolites were originally present as glucuronides. However, Sandberg \& Slaunwhite (1958) found that only about half of the radioactivity in the urine could be extracted after enzymic hydrolysis of the urine, a value similar to that (45-75\%) found in the present investigation. The yield of radioactivity obtained by enzymic hydrolysis was not necessarily increased by using large amounts of enzyme and long incubation times, since, as shown in our experiments, the use of large amounts of enzyme may lead to a decreased recovery of radioactivity, presumably due to absorption of the metabolites on to the protein of the enzyme preparation (Lehninger \& Scott, 1947). The enzymic hydrolysis of pregnanediol glucuronide in aqueous solution appears to be complete after $4 \mathrm{hr}$. of incubation (Wakabayashi \& Fishman, 1961). In the present investigation the majority of the radioactivity was released after $18 \mathrm{hr}$. of incubation and the recovery of radioactivity was usually further increased by incubation of the urine for $48 \mathrm{hr}$. The yield of radioactivity obtained by enzymic hydrolysis seems to vary from sample to sample of urine, depending on the presence or absence of inhibitors in the urine (Stempfel, Sidbury \& Migeon, 1960; Marsh, 1961) and the relative proportions of the conjugates of the different metabolites, which are hydrolysed at different rates (Wakabayashi \& Fishman, 1961).

Although continuous extraction of the urine with ether after enzymic hydrolysis and adjustment to $\mathrm{pH} 1$ liberated about $8.5 \%$ of radioactivity, an amount similar to that found by Sandberg \& Slaunwhite (1958), it was possible that much of this radioactivity was released from metabolites originally present as glucuronides, which had escaped hydrolysis, and not as conjugates with sulphuric acid. The application of procedures more specific for the hydrolysis of steroid sulphates liberated smaller amounts of radioactivity. The largest yield of radioactivity was obtained by extraction with butanol, but even after butanol extraction about $10-15 \%$ of the radioactivity was not recovered from the urine.

It was shown by Contractor \& Pearlman (1960), Chang, Slaunwhite \& Sandberg (1960) and Harkness \& Fotherby (1961) that progesterone can be metabolized to compounds more polar than pregnanediol although the quantitative significance and 
identities of these metabolites have not been definitely established. The results of the countercurrent distributions (Tables 5 and 6) show that, though 5 $\beta$-pregnane-3 $\alpha, 20 \alpha$-diol and its isomers (which in the distributions occurred in the less polar non-ketonic fraction) are the main metabolites of progesterone, a considerable amount of radioactivity $(12.5 \%$ of that in the freely extractable and enzyme-hydrolysed extracts) was found in the compounds more polar than pregnanediol. Also, whereas in the non-ketonic fraction of the freely extractable or enzyme-hydrolysed extracts most of the radioactivity was in the less polar component, in the ketonic fraction a greater proportion of the radioactivity was in the medium polar and, more particularly, the polar components. The acidhydrolysed fraction also contained a high proportion of polar metabolites; these may have arisen from metabolites that had escaped the previous enzymic hydrolysis and extraction, or may be artifacts produced by hydrolysis with hot acid.

The use of liquid-scintillation counting for determining the radioactivity in crude extracts was limited by the falsely high counting rates often produced, and these persisted for several hours after the extract was completely dissolved in the scintillator. This phenomenon was also observed by Brown \& Badman (1961) with alkaline solutions of tissue homogenates. They found that these high counting rates were greatly diminished by acidification of the solution, but this procedure was not successful with most of the extracts obtained in the present investigation. High counting rates were also produced by the addition to the scintillator of butanol extracts of urine that were not radioactive. These disadvantages were overcome by using gasflow counting for the crude extracts.

\section{SUMMARY}

1. After the intravenous administration of $\left[4^{-14} \mathrm{C}\right]$ progesterone to five adrenalectomized ovariectomized women the majority of the radioactivity (47-68\%) was excreted within the first 4 days although small amounts of radioactivity were detectable in the urine during the subsequent 7 days.

2. Various ways of extracting the radioactivity from urine were investigated.

3. Countercurrent distribution of extracts from the urine of a woman who had received $20 \mu \mathrm{c}$ of [4-14 C]progesterone showed that pregnanediol and its isomers were the main metabolites.
4. In the freely extractable and enzymehydrolysed extracts $12.5 \%$ of the radioactivity was associated with metabolites more polar than pregnanediol, whereas in the acid-hydrolysed extract there was a preponderance of polar metabolites and about $50 \%$ of the radioactivity was associated with the more polar compounds.

R.A.H. is indebted to the University of Edinburgh for a Research Fellowship.

\section{REFERENCES}

Abul-Fadl, M. A. M. (1957). Biochem. J. 65, 16P.

Brown, W. O. \& Badman, H. G. (1961). Biochem. J. 78, 571.

Bucher, N. L. R. \& Geschickter, C. F. (1940). Endocrinology, 27, 727.

Burstein, S. \& Lieberman, S. (1958). J. biol. Chem. 233, 331.

Chang, E., Slaunwhite, W. R. \& Sandberg, A. A. (1960). J. clin. Endocrin. 20, 1568.

Cohen, S. L. \& Marrian, G. F. (1936). Biochem. J. 30, 57.

Contractor, S. F. \& Pearlman, W. H. (1960). Biochem. J. 76, 36.

Craig, L. C., Hausmann, W., Ahrens, E. H. \& Harfenist, E. J. (1951). Analyt. Chem. 23, 1236.

Davis, M. E. \& Plotz, E. J. (1958). Amer. J. Obstet. Gynec. 76, 939.

Fotherby, K., Colas, A., Atherden, S. M. \& Marrian, G. F. (1957). Biochem. J. 66, 664.

Fotherby, K. \& Love, D. N. (1960). J. Endocrin. 20, 157.

Gallagher, T. F., Bradlow, H. L., Fukushima, D. K., Beer, C. T., Kritchersky, T. H., Stokem, M., Eidinoff, M. L., Hellman, L. \& Dobriner, K. (1954). Recent Progr. Hormone Res. 9, 411.

Haigh, C. P. (1954). Nucleonics, 12, 34.

Harkness, R. A. \& Fotherby, K. (1961). Biochem. J. 80, 8P.

Lehninger, A. L. \& Scott, W. W. (1947). Endocrinology, 40, 9.

Levvy, G. A. (1952). Biochem. J. 52, 465.

MoKenna, J. \& Norymberski, J. K. (1960). Biochem. J. 76, $60 \mathrm{P}$.

Marsh, C. A. (1961). Biochem. J. 79, 21 P.

Pearlman, W. H. (1957). Biochem. J. 67, 1.

Peng, C. T. (1960). Analyt. Chem. 32, 1292.

Sandberg, A. A. \& Slaunwhite, W. R. (1958). J. clin. Endocrin. 18, 253.

Stempfel, R. S., Sidbury, J. B. \& Migeon, C. J. (1960). J. clin. Endocrin. 20, 814.

Stitch, S. R. (1959). Biochem. J. 73, 287.

Swank, R. K. (1958). In Liquid Scintillation Counting, p. 23. Ed. by Bell, C. G. \& Hayes, F. N. London: Pergamon Press Ltd.

Wakabayashi, M. \& Fishman, W. H. (1961). J. biol. Chem. 236, 996. 